\title{
Study on English Teaching Mode Innovation of Colleges from the Perspective of Big Data
}

\author{
Wenhua Wang \\ Leshan Vocational and Technical College, Leshan, 614000, China
}

Key words: Big data, College English, Teaching mode, Innovation.

\begin{abstract}
Big data is an important reform in the field of information technology. As big data is applied in people's production and life more and more widely, a great impact is exerted on the college English teaching in China. Under the new time background, traditional college English teaching mode has become not suitable for the development of times, and the innovation of college English teaching mode becomes urgent. As far as the conditions of college English teaching in China at the present stage are concerned, many colleges carry out English teaching based on the application of big data. But since no big data application foundation system has been established, the traditional teaching ideas have not be updated, and inadequate efforts are made to go into students' personalized information, the advantages of big data have not be taken full of in English teaching in many colleges, having wasted good teaching resources, and also hindered the development of English teaching of Chinese colleges. This paper is intended to discuss "English teaching mode innovation of colleges from the perspective of big data", with a hope to contribute to the optimization of English teaching of Chinese colleges.
\end{abstract}

\section{Introduction}

The $21^{\text {st }}$ century is an era of science and technology productivity, when big data is widely applied in our production and life, and brings about profound changes in various fields, without exception for education. Big data-based education has a great impact on Chinese colleges' education. Under the new time background, Chinese colleges, in order to respond to the call of times, implement new-type teaching methods, such as webucation, distance education, and so on, and informationized education is also widely constructed. Since big data-based college English teaching is under-developed in China, and we lack experience of big data application, there are many problems in the development process of big data-based college English education, including difficulties in data collection and personalized educational program setting, oversimple application of big data, and so on. In view of this, educators should go into the problems in innovation of college English teaching mode from the perspective of big data, and grasp the opportunities of times, to greatly develop Chinese college English teaching.

\section{Analysis of Situation of Chinese College Teaching under the Context of Big Data Application}

Since the "big data development" was proposed at the third plenary session of the $18^{\text {th }}$ Central Committee of the Communist, remarkable achievements have been made in the application of big data in China. From the aspect of education, however, traditional education mode has not completely replaced yet, and Chinese colleges encounter many challenges while meeting the opportunities brought by big data. Since the colleges are at different education level, and their strength also varies, their levels of big data application also are different, mainly at four levels: failure to apply big data; having applied big data on a small scale to realize simple digitalized teaching; having established a 
mature online English teaching platform to facilitate data and information collection and exploration and learning about students' primary needs; having equipped with a college English teaching information system, so as to be able to realize data collection, exploration and analysis, and make personalized teaching program.

\section{Colleges Failing to Apply Big Data}

College English education based on application of big data requires students to learn related system of behavior digitization and process recording. System construction will take a lot of time and funds. Because of this, many colleges only apply big data to realize English learning materials sharing on the internet, and ignore collection of students' learning behavior data, deep exploration of related data, and setting of personalized teaching program.

\section{Colleges Having Applied Big Data on A Small Scale}

Big data-based English education has enriched the channel of English education for colleges. Many colleges have reached an agreement with education companies, and add "webucation", to preliminarily realize the simple application of big data via analyzing the time and counts of students' accessing to the internet. "Webucation" has largely benefited students, so that students can have access to more resources, and broaden their horizon.

\section{Colleges Capable of Applying Big Data on A Large Scale}

Those colleges that are capable of applying big data on a large scale usually will depend on the third party to develop a relatively mature platform for English education. Such platform is provided with perfect ports, such as tracking, recording and data collection, and can basically meet the need of information collection of English teaching of colleges. Through analyzing the information tracked, recorded and collected by the third party, colleges can roughly grasp students' behaviors, features and abilities in English learning. Besides, big data platform enriches colleges' English teaching resources, promotes interaction between students and teachers, and is good for cultivating students' personalities, arousing students’ learning interest, and optimizing teaching evaluation.

\section{Colleges Capable of Independently Applying Big Data}

Independently applying big data in teaching is demanding for colleges in respect of manpower, material resource and financial resource. Thus, there are few colleges can apply big data in teaching in China. But it cannot be denied that the English teaching of colleges that are capable of applying big data independently are more distinctive and superior from the aspects of both education and humanity. Besides, the colleges can specially reserve ports for collecting and integrating other systems in future when independently constructing their own education information system, to enrich their education information system. Not only the colleges' education data can be enriched, but also more scientific and rational students developing scheme can be made.

\section{Analysis of Problems in Application of Big Data in College English Teaching}

\section{Lack of Sound Foundation Facilities}

The application of big data cannot do without data collection, and data collection cannot do without a digitized learning process. According to the situation of most Chinese colleges, however, most colleges don't carry out a digitized teaching process, and there are difficulties for students' to learn data collection accordingly, and designing scientific and rational personalized teaching program based on data also becomes an "idle talk".

\section{Lack of Right Teaching Ideas}

Firstly, the application of big data in teaching system needs to consume a lot of time and manpower, and colleges must provide adequate manpower, material resources and financial resources. But many 
colleges still adhere to the traditional education ideas, and many teachers lag behind ideologically and have no consciousness of reforming their own teaching mode at all. Thus, the application efficiency of digitized teaching system in colleges is considerably low, and the web-based English teaching system even exists in name only in some colleges. As a result, big data-based college English teaching cannot play a proper role at all, but is just regarded as a "face-saving project".

\section{Incapability of Technology Application}

Big data-based college English teaching is demanding for college English teachers, requiring college English teachers to have the consciousness of using the new-type teaching mode, and be capable of applying the new-type teaching mode. The actual situation, however, shows that many college English educators are not proficient in computer and network, incapable of applying web-based teaching methods, and even strongly contradict web-based education. As a result, many educators' efficiency of application of big data is low. They spend a lot of time and energy, but haven't improve their teaching quality. Besides, although an information collection system can provide students' learning data, if educators are capable of analyzing and analyzing data, it is difficult for them to apply data to describe students' image and make rational personalized training program.

\section{Analysis of Strategy for College English Teaching Mode Innovation from the Perspective of Big Data}

The goal of applying big data is to help educators to identify students' personalities, and design proper teaching mode according to students' personalities. To realize this goal, colleges should consciously change their teaching idea of "striving for maintaining the average learning level of class" and the traditional management scheme of "regular test and centralized management", timely discard the practice of obtaining students' learning level data in the traditional teaching mode, turn to big data analysis based on modern information approach to learn about students' performance, analyze students' characteristics and personalities, and design an optimal learning scheme for them.

\section{Changing College English Teaching Ideas}

Big data-based college English teaching can be regarded to truly " teach students in accordance of their aptitude”, because students’ learning process can be learned about via big data analysis based on modern information approach, and scientific data and materials are good for teachers to have a deep understanding of students' learning data and make proper personalized teaching program. At the present stage, many Chinese colleges use distance education, online extracurricular education and web-based college English teaching system in English teaching, but many colleges still adhere to traditional and obsolete educational ideas. Traditional educational ideas do not only hinder the development of college English education, but also put colleges' web-based education information system in a position in name, so that students' personalized needs cannot be met, and the educational idea of teaching students in accordance of their aptitude cannot be completely implemented. In view of this, colleges should closely follow the pace of era development, reform the existing English teaching system on the basis of their own actual situation, put the available reform approaches into rational use to change the teaching ideas of the teachers and students, create a good atmosphere for informationized and digitized English teaching of colleges, make more efforts in collection, analysis and application of data, and give full play to the application of big data as far as possible.

\section{Establishing An Intelligent English Education Platform}

An intelligent English teaching platform is helpful to implement whole-process and digitized college English education, show the features of vocational English teaching, and identify students' features of English learning. Besides, big data-based college English education (via the mature platforms such as MOOC, Flipped Classroom, etc.) can break the space and time limitations of education, and largely broaden students' horizon. It is worth mentioning that since it is highly cost to construct an 
independent intelligent English teaching platform, and the existing network platforms of colleges are insufficient for learning about students' learning information, colleges can consciously cooperate the mature web-based English teaching platforms, to make use of others to set personalized information capture port to capture students' learning data and information, and consolidate the foundation for designing personalized training program.

\section{Rationally Using Big Data Information to Establish Personality Cultivating Program}

An intelligent English teaching platform can provide educators with more behavior information of college students. Through analysis, educators can scientifically grasp students' learning characteristics, such as learning pattern, students' advantages, advancement, and best learning time, and so on. Through summarization of the aforementioned information, educators can figure out students' near-term learning needs, and then make a more detailed and scientific training program. After implementing the program, educators can track students' post feedback, and constantly adjust the program on this basis to enhance students' enthusiasm for English learning, raise students' English learning efficiency, form a virtuous cycle of English learning, and promote students' English learning to advance uninterruptedly.

\section{Conclusion}

Under the context of new time background, traditional college English teaching mode has become not suitable for the needs of era development, and it is urgent for colleges to innovate their English teaching mode. To sum up, innovation of college English teaching mode is inevitable for the development and reform of college English education from the perspective of big data. Educations and college authorities should actively change their teaching ideas, take full account of their actual situation, consciously enhance their application skills, and constantly improve themselves, so as to continuously optimize their teaching methods and teaching contents, give full play to the application of big data, greatly arouse students' enthusiasm for participating in teaching, largely improve students' comprehensive English ability, and provide high-quality comprehensive English talents to the country and the society.

\section{References}

[1] Xu Liyun. Study on College English Teaching Mode Innovation from the Perspective of New Media. Modern Education, 2015, 11: 43.

[2] Xiang Rui. Study on College English Teaching Mode Innovatio in the Era of Big Data-Case Study of "Rotating Class" of Bohai University. Journal of Lanzhou Institute of Education, 2016, 05: $141-142+174$.

[3] Luo Na. Exploration of College English Teaching Innovation Based on Application of Big Data. Science and Technology Consulting Herald, 2016, 21: 133-134.

[4] Wang Qingbiao, Li Qingxue, Chu Mingxiang, Liu Chanjuan, Hu Yongqiang. Study on Civil Engineering English Teaching Mode Innovation from the Perspective of Internationalization. Theory and Practice of Contemporary Education, 2014, 05: 101-104.

[5] Zeng Jianping. Exploration of Translation Course Teaching Mode of English Majors in Colleges from the Perspective of “Internet Plus”. Overseas English, 2016, 20: 83-84. 